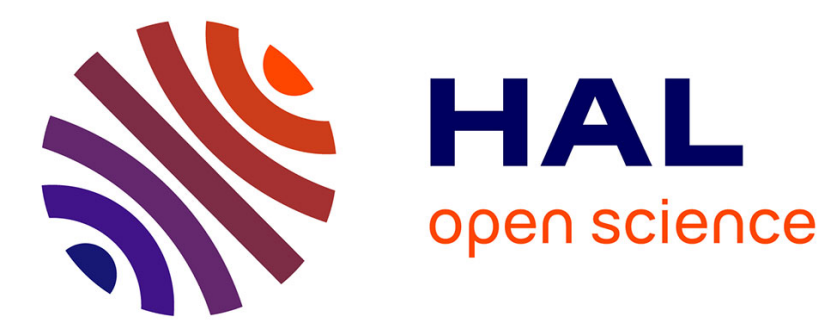

\title{
Target Bankruptcy Risk and its Impact on Going-private Buyout Performance and Exit
}

Sudi Sudarsanam, Mike Wright, Jian Huang

\section{To cite this version:}

Sudi Sudarsanam, Mike Wright, Jian Huang. Target Bankruptcy Risk and its Impact on Going-private Buyout Performance and Exit. Corporate Governance: An International Review, 2011, 19 (3), pp.240. 10.1111/j.1467-8683.2011.00854.x . hal-00627547

\section{HAL Id: hal-00627547 https://hal.science/hal-00627547}

Submitted on 29 Sep 2011

HAL is a multi-disciplinary open access archive for the deposit and dissemination of scientific research documents, whether they are published or not. The documents may come from teaching and research institutions in France or abroad, or from public or private research centers.
L'archive ouverte pluridisciplinaire HAL, est destinée au dépôt et à la diffusion de documents scientifiques de niveau recherche, publiés ou non, émanant des établissements d'enseignement et de recherche français ou étrangers, des laboratoires publics ou privés. 


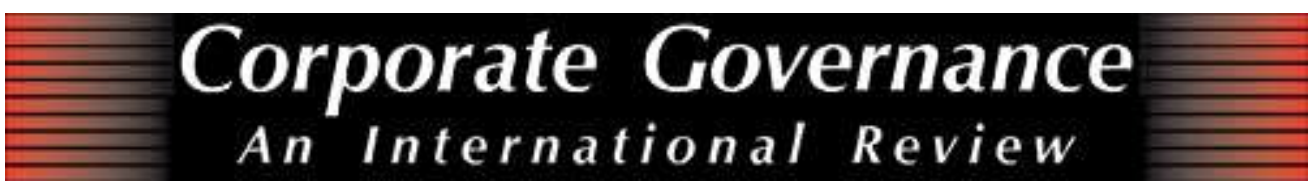

\section{Target Bankruptcy Risk and its Impact on Going-private Buyout Performance and Exit}

\begin{tabular}{|r|l|}
\hline Journal: & Corporate Governance: An International Review \\
\hline Manuscript ID: & CGIR-2010-0068PE.R3 \\
\hline Manuscript Type: & Private Equity Issue \\
\hline Keywords: & $\begin{array}{l}\text { Board Composition < Board of Director Mechanisms, Mergers \& } \\
\text { Acquisitions < Market Control Mechanisms, Corporate Financial } \\
\text { Performance < Firm-Level Governance Outcomes }\end{array}$ \\
\hline \multicolumn{2}{|l}{} \\
\hline
\end{tabular}

\section{SCHOLARONE \\ Manuscripts}




\title{
Target Bankruptcy Risk and its Impact on Going-private Buyout Performance and Exit
}

\begin{abstract}
Manuscript Type: Empirical

Research Question/Issue: What is the impact of bankruptcy risk on whether listed corporations are likely to be bought out by private equity firms and on the subsequent exit, including bankruptcy, of private equity backed public to private buy-outs?
\end{abstract}

Research Findings/Insights: Using a sample of 246 UK companies that went from public to private (P2P) company status from 1997 to 2005, we find that going private companies have significantly higher default probability. Private equity firms sponsoring P2P deals acquire firms with higher risk of bankruptcy than non-acquired firms that remain public. We find evidence that high receivership risk at going private increases the chance that the target will end up in receivership, but post-P2P bankruptcy likelihood is less when the $\mathrm{P} 2 \mathrm{P}$ is a management buyout rather than any other form of buyout. Independent boards of pre-P2P targets promote $\mathrm{P} 2 \mathrm{P}$ deals and reduce the chances of bankruptcy after the buyout, suggesting a good corporate governance structure makes a positive contribution to bankruptcy avoidance after going private transactions.

Theoretical/Academic Implications: Our finding that P2P deals involve targets with a higher risk of bankruptcy adds to theoretical insights about private equity as, in contrast to previous research, it suggests that PE firms are not deterred by the risk of financial distress but consider it a value creating opportunity. Our use of the option pricing framework represents a first and novel attempt at measuring bankruptcy risk and its impact on the ability of private equity firms to achieve effective turnaround. We find a link between better governance of the target pre-P2P and lower bankruptcy risk since where the PE investor inherits a strong governance structure, manifested in independent boards, chances of subsequent bankruptcy are reduced. Similarly, where the P2P acquisition is a management buyout, the probability of bankruptcy, post-P2P, is reduced, suggesting lower informational asymmetries and better alignment of interests between managerial and private equity investors. Although, due to the small number of receivership exits in our sample of P2P firms, the results are not as strong as we would like, a more extended analysis involving a larger sample over a longer period, in particular of firms exiting through bankruptcy is expected to produce stronger results. Our results provide a sufficient basis to warrant such further analysis.

Practitioner/Policy Implications: Private equity backed P2Ps of listed corporations with high bankruptcy risk augment the market for corporate control as they provide an alternative purchaser to traditional acquirers. Our finding that high bankruptcy risk at going private increases the chance the target will end up in receivership suggests a need for caution on the part of private equity firms since the turnaround of $\mathrm{P} 2 \mathrm{P}$ targets appears to depend on how seriously distressed they are at the P2P stage. Private equity firms, therefore, need to engage in careful due diligence. Private equity firms need to give attention to the nature of the pre- 
$\mathrm{P} 2 \mathrm{P}$ governance regime when selecting $\mathrm{P} 2 \mathrm{P}$ targets, in particular the extent to which better monitoring by independent directors has been in place and where there is greater alignment of interests between managers and LBO sponsors since these contribute to bankruptcy avoidance. For listed corporations, our findings suggest that strengthening of independent boards may contribute to timely decisions to sell troubled corporations.

Keywords: corporate governance; private equity; distress; going private; LBO; bankruptcy 


\section{Performance and Exit \\ INTRODUCTION}

Target Bankruptcy Risk and its Impact on Going-private Buyout

A leveraged buyout (LBO) is an acquisition of a business mostly with cash, the cash being raised with a preponderance of debt issued by the acquirer. Management buyouts and management buyins are respectively LBOs where incumbent top managers of the target firms are sponsors or co-sponsors of the LBO deal and where such management is excluded. Goingprivate is a type of LBO where the shareholders in the publicly listed target are bought out, typically supported by private equity firms, and the company becomes privately owned. It is also known as a public-to-private (P2P) buyout. P2Ps can be either management buyouts or management buyins. In the UK, P2Ps have become prominent during recent years. P2P transactions on average account for about $3 \%$ in deal number and $20 \%$ in value of total LBO activities (CMBOR, 2009). The increasing importance of P2Ps raises interesting questions about the motivations and expected sources of value creation that drive these deals (Kaplan \& Stromberg, 2008; Wright, Amess, Weir \& Girma, 2009). Many US studies, principally relating to the 1980s, have reported substantial gains for target shareholders when P2P deals are announced (DeAngelo, DeAneglo \& Rice, 1984; Lehn \& Poulsen, 1989; Kaplan, 1989; Marais, Schipper \& Smith, 1989; Frankfurter \& Gunay, 1992; Travlos \& Cornett, 1993) and empirically investigated the value sources. Cumming, Siegel and Wright (2007) review the literature on these and provide evidence that more astute financial management, labour and asset productivity improvements, more robust governance and better managerial incentive alignment contribute to performance improvement and value creation. 
Following a P2P deal, the concentrated equity ownership of the private equity sponsor and the high leverage are said to provide more effective managerial monitoring, thereby contributing to greater value creation than in the pre-LBO period characterised by divorce of management control from share ownership (Jensen, 1991). This argument is premised upon corporate governance failure in the pre-P2P firm. Several other explanations have been put forward as motivations for P2P LBOs and for their sources of value (Renneboog, Simons \& Wright, 2007). Among these is the persistent undervaluation of target firms while being publicly listed. Such undervaluation increases the firm's cost of capital and prevents them from pursuing valuable investment opportunities. Ownership by specialist private equity firms may allow them to exploit valuable growth opportunities more effectively. This suggests that in the pre-P2P period the target may have experienced low growth and poor operating performance (Lehn \& Poulsen, 1989; Kim \& Lyn, 1991).

DeAngelo and DeAngelo (1987) argue that the advantages of going private include improved company performance, tax savings due to high leverage and potential improvement in the firm's competitive position. Going private deals may also result in better incentives for managers because of performance-driven incentive elements e.g. equity ratchet and stock options. However, the US and UK empirical evidence on the factors influencing the going private decision is mixed (Lehn \& Poulsen, 1989; Kaplan, 1989; Halpern, Kieschnik and Gotenberg, 1999; Guo, Hotchkiss \& Song, 2010; Weir, Laing \& Wright,2005a;Renneboog et al., 2007). We focus on financial distress as an aspect of the rationale for P2Ps that has received limited attention. Opler and Titman (1993) argue that since firm failure is more likely following a buyout due to the higher debt burden, the potential for significant financial distress costs will deter P2P buyouts with high bankruptcy potential. Recent studies have explored the failure rate of LBOs (Stromberg, 2008; Wilson, Wright \& Altanlar, 2009). Wilson et al. (2009) find that private equity-backed LBOs are less likely to fail than non- 
private equity backed LBOs, pointing to the superior governance skills, resources and capabilities that private equity firms have compared to listed corporations in managing companies and avoiding bankruptcy. Acquiring firms with high bankruptcy potential to turn them around post-buyout is a challenge of greater magnitude than acquiring relatively healthy firms and keeping them away from bankruptcy. There is very little research to date which examines whether LBO-sponsors in general and private equity firms in particular successfully meet this challenge. This paper contributes to the literature by providing evidence on the impact of bankruptcy risk faced by the P2P targets, an important issue not addressed directly by prior studies.

We address a specific question: are private equity firms able to acquire potentially bankrupt targets and improve their performance so as to avoid bankruptcy? We seek to answer this question in the context of the leveraged buyout $(\mathrm{P} 2 \mathrm{P})$ of publicly listed firms and by relating post-buyout bankruptcy to this ex ante bankruptcy risk.

We seek to make four contributions to the existing literature. First, we advance the theoretical arguments concerning the effect of distress costs on $\mathrm{P} 2 \mathrm{P}$ activity by providing a contrary hypothesis to previous research in which we suggest distress will be attractive in encouraging P2Ps because of the turnaround opportunity it represents. Second, and related to the first, we make an important empirical contribution. Opler and Titman (1993) consider the impact of financial distress cost, measured by $R \& D$ intensity, on target shareholder value gains. Research and Development (R\&D) intensity, however, is not a reliable proxy for bankruptcy risk or distress costs. We employ direct measures of bankruptcy risk - default probability and proximity to default - estimated from stock market data using an option pricing model. Third, we contribute to the literature on the effectiveness of the governance mechanisms associated with private equity firms that has focused upon their role in improving profitability and reducing costs in portfolio by addressing the neglected issue concerning 
whether private equity firms successfully turn around distressed P2P targets. While a listed corporation with high bankruptcy risk may present turnaround potential, this high risk when associated with the high leverage in $\mathrm{P} 2 \mathrm{P}$ deals may increase the chances of its failure under private equity ownership. In addressing this issue we also make a policy contribution since regulators have expressed concern about the potential dangers of P2P transactions (Financial Services Authority, 2006). However, to date, there is no evidence to inform this debate. We provide new evidence on the relationship between bankruptcy risk of P2P targets and their subsequent fate under private equity ownership. Fourth, we make a contribution to the general corporate governance literature by highlighting (i) the role of private equity backed P2Ps in extending the market for corporate control beyond traditional acquisitions of companies at risk of bankruptcy and (ii) the role of boards pre-P2P in taking timely decisions to sell troubled companies.

A study of P2Ps in the UK is especially important for a number of reasons. First, the UK P2P market is second only in size (both deal value and numbers) to that of the US P2P market. Second, while the UK is superficially similar to the US as an Anglo-Saxon institutional environment, the UK market focuses on self-regulation of takeovers, where, for example, hostile bids face fewer obstacles in the form of frustrating action by target managements than in the US. Third, UK P2Ps make more use of privately placed mezzanine (subordinated) debt with junk bonds being very rare. Fourth, the leverage in UK P2P transactions is generally below that in US cases (CMBOR, 2009). Fifth, the UK tax regime relating to the treatment of interest on debt differs from that in the US (Treasury Select Committee, 2006). Sixth, there are marked differences between the creditor-friendly UK and the debtor-friendly US bankruptcy regimes (Citron, Wright, Rippington \& Ball, 2006). Thus the characteristics, in particular, bankruptcy risk of targets, in $\mathrm{P} 2 \mathrm{P}$ deals and how they influence subsequent exit in the UK may differ significantly from the US deals. 
Using a sample of 246 UK companies (i.e., all P2Ps for which information is available) that went private during 1997 to 2005, and a control sample of similar non-going private firms, we find that $\mathrm{P} 2 \mathrm{Ps}$ have greater proximity to default. Importantly, we find that high bankruptcy risk provides an incentive for firms to go private. We confirm other research that $\mathrm{P} 2 \mathrm{P}$ targets have a lower market to book value ratio, a lower price/earning ratio, lower recent growth rate and smaller boards of directors than control firms. They are also relatively small and have suffered stock market neglect.

High bankruptcy risk at going private increases the chance that the target will end up in receivership but this chance is reduced where managers hold larger shares or the P2P acquisition is a management buyout. Thus managerial alignment seems to improve the chances of turnaround. This confirms that managerial incentive alignment is an effective governance mechanism and contributes to the success of turnaround. This evidence is consistent with Wilson et al's (2009) study reporting higher likelihood of bankruptcy of management buyin targets than management buyout targets after buyout.

The paper is organized as follows. Section 2 discusses the theories relating to the going private decision and develops the hypotheses that are subsequently tested. Section 3 describes the methodologies and data used in this research. Section 4 presents and discusses the results. Section 5 contains a summary of the empirical findings and suggestions for future research.

\section{THEORETICAL FRAMEWORK}

Traditional motivations for $\mathrm{P} 2 \mathrm{P}$ deals identified in the literature include resolution of the agency problem in public corporations with diffused ownership and weak corporate monitoring by owners, unutilised debt capacity and associated tax advantages, reducing regulatory costs associated with publicly listed firms and correcting the undervaluation of the pre-P2P target firms. By taking the targets private, the LBO-sponsors seek to avoid the costs 
and inefficiencies associated with their operations, financial structures and governance mechanism. Various authors have developed arguments supporting these motivations. These include: Reducing the agency costs of equity manifested in the abuse of free cash flow by incumbent managers by robust management monitoring by the board of directors (Jensen, 1986 and 1991); correcting corporate governance failure in the pre-P2P targets (Jensen, 1993; Denis, 1994; Weir et al, 2005a; Renneboog et al, 2007); improving managerial monetary and non-monetary incentives after buyout (Halpern et al, 1999); avoiding the regulatory costs of being a publicly listed corporation (Travlos \& Cornett, 1993); exploiting target undervaluation and the opportunity to realise the full target value (DeAngelo et al, 1984); and exploiting the benefits of unused debt capacity to increase leverage and reap the tax benefits of leverage (Jensen, 1986; Lowenstein, 1985).

Few of the above P2P studies examine bankruptcy avoidance as a motive for P2P. No previous study has examined the impact of the bankruptcy risk profile of $\mathrm{P} 2 \mathrm{PP} 2 \mathrm{P}$ targets on their fate under private equity ownership i.e. whether they do indeed go bankrupt post-P2P buyout.

\section{Bankruptcy risk and going private deals}

Bankruptcy or financial distress avoidance as a motive to go private: Opler and Titman (1993) argue that going private represents a trade-off between the potential gains from, for example, incentive realignment with resultant reduction in agency costs, and the possible costs of financial distress should the firm fail. Firm failure may be more likely following a buyout due to the higher debt burden. Opler and Titman consider and find support for financial distress cost, proxied by R\&D intensity, as a factor deterring a P2P buyout. Besides the potential measurement problem in using R\&D intensity as an accurate measure of bankruptcy risk or distress costs, we suggest that the conceptual argument that potential financial distress costs may deter P2Ps may be misplaced. 
We adopt a contrary view to Opler and Titman (1993) in arguing that firms experiencing financial distress or potential bankruptcy before the $\mathrm{P} 2 \mathrm{P}$ may be attractive to LBO sponsors. Such acquirers may find in distressed targets the opportunity to improve performance. Our review above suggests a number of reasons why post-buyout performance may improve, thereby reducing bankruptcy risk. Financially distressed P2P targets may also be bought more cheaply than financially healthy firms. Financially distressed targets may also not be highly leveraged thereby foregoing tax benefits in the pre-P2P period. Incentive realignment from increased managerial equity stakes and improved governance may also help turnaround performance and reduce bankruptcy risk. Free cash flows tightly monitored by LBO sponsors may also offset bankruptcy risk. Reduction in bankruptcy risk, in turn, enhances the firm's debt capacity and the scope for realizing the tax benefits from higher leverage.

PE firms typically invest in those buy-outs which they can exit within two to five years. They trade off the downside risk of buying distressed firms against the upside potential of a successful turnaround and value gains. If this motivated a P2P sponsor, then it would look for targets with a higher bankruptcy risk profile. Therefore, we test the following hypothesis:

\section{H1: P2P targets are more likely than non-P2P control firms to display high bankruptcy risk.}

Outcome of bankruptcy risk. While financially distressed firms may be rescued from possible bankruptcy by private equity acquirers, they also carry a higher risk that the expected turnaround in the post-P2P period may not be achieved. Private equity firms are regarded as having specialist skills to select and monitor portfolio companies that are underperforming and whose performance they are able to improve (Kaplan \& Stromberg, 2008; Cressy, Malipiero \& Munari, 2007). In acquiring a distressed listed corporation they reckon that the stock market undervalues the company (Weir, Laing \& Wright, 2005b) and their 
specialist governance skills will allow them to restructure the business to realize gains that other investors are unable to. However, while private equity firms will conduct due diligence at the time of the investment, even in respect of listed corporations this may be incomplete. Private equity acquirers, as other acquirers, will likely have access only to limited non-public information about the company in memoranda prepared by the investment bank charged with selling the company (Boone and Mulherin, 2007). As a result of this limited access to information about the real underlying problems of the business, the high bankruptcy risk at the time of the $\mathrm{P} 2 \mathrm{P}$ may doom the acquisition to failure leading to bankruptcy or receivership (we use these terms interchangeably in the rest of the paper since receivership refers to the UK bankruptcy process for distressed firms) despite the turnaround capabilities of the acquirer. Hence, we test the following hypothesis:

H2: High bankruptcy risk at going private increases the chance that the target will end up in receivership.

We investigate how many of the P2P acquisitions subsequently result in such a dire outcome and how many avoid that fate. We also investigate the relationship between bankruptcy risk at the time of the $\mathrm{P} 2 \mathrm{P}$ deal and the eventual exit through bankruptcy compared to other forms of exit such as return to the stock market, trade sale or a secondary buyout by management buyout or management buyin.

\section{DATA AND METHODOLOGY}

\section{Data collection}

From a population of 258 firms that underwent public-to-private buy-outs during 1997 to 2005 identified from the Thomson Financial's SDC database (only completed deals included) and the CMBOR database, we constructed an initial sample of 246 UK publicly listed companies Data non-availability as regards explanatory variables and stock returns restricts the population to a slightly smaller sample. We chose 1997 as the start year as this marked 
the resurgence of P2Ps and 2005 as the end year in order to give sufficient time for exit outcomes to be determined for most of our sample firms. Table 1 below shows the number and value of going private deals by year. For the exit analysis we use only that subsample of firms for which we had exit data at 31 December 2005.

\section{\{Insert Table 1 about here\}}

From our sample analysis, we observe that going private companies are drawn from various industries but the sample industry distribution pattern is very different from that of Financial Times Stock Exchange All Share Index firms. Most of the sample companies fall into industries like textiles, construction, restaurants and pubs, engineering and food producers (accounting for more than $26 \%$ of total sample), which is in line with the industry distribution from the US sample of Kim and Lyn (1991). For the entire sample, the median (mean) value of a going private deal is $£ 62 \mathrm{~m}(£ 122 \mathrm{~m})$ suggesting some large deals that skew the distribution. The mean and median values show an erratic pattern over time often being driven by single large deals e.g. the Debenhams deal in 2003.

A control sample is then constructed as a benchmark for the P2P sample. Some prior US studies are based on random selection of control firms (Kim \& Lyn, 1991; Halpern et al, 1999). Non-random, matched sampling is also used in acquisition studies (Palepu, 1986). Similar to Denis (1992), we select the control firms by, first, industry and, then, size. Within each Datastream 2-digit Standard Industrial Classification code industry, a matching company closest in terms of size i.e. sales revenue for each sample P2P company is selected. Although we selected the control firm closest in firm size measured by sales revenue, we note that the $\mathrm{P} 2 \mathrm{P}$ and control samples still differ in terms of this size measure. Thus this control is necessarily imperfect but is preferred to random selection as it provides a closer comparator. We choose sales revenue rather than market value of equity as a size control because the latter is likely to be biased down due to undervaluation (see below for further discussion of 
undervaluation as a motivation for a P2P buyout). The selected control firm must continue to be listed on the London Stock Exchange after the P2P of its sample counterpart. We were unable to find matching control firms for a small number of the $\mathrm{P} 2 \mathrm{P}$ firms with the requisite data thereby reducing the sample for the different analyses reported below.

\section{Variables}

Accounting data including sales growth, debt, size, free cash flow, and price to earnings ratio and market to book value ratio are taken from Datastream. Datastream also provides share price data for the calculation of abnormal returns. Corporate governance variables data come from the company annual accounts.

Dependent variables. Our analysis comprises two dependent variables. First, to identify the determinants of the going private decision we use a dummy variable that equals 1 where the firm is a P2P target and 0 otherwise. Second, the exit type i.e. bankruptcy or others including the continued holding of the target firm in the LBO sponsor's portfolio is the dependent variable in our analysis of the impact of bankruptcy risk on LBO exit. Alternative exit types are discussed further below. Exit is a dummy variable assuming a value of 1 for receivership and 0 for other exits or retention in the portfolio at 31 December 2005.

Independent variables. Our principal focus is on financial distress/ bankruptcy risk in P2Ps. Opler and Titman (1993) use the target R\&D/sales to proxy for the financial distress costs. In this study, we also employ intangibles that include capitalised R \& D costs and other intangible assets as another measure of potential distress costs. If we accept the Opler and Titman's deterrent effect argument, the higher the intangibles intensity, the lower is the probability of a P2P. Unlike in the US, some R\&D costs may be capitalized in the UK. High intangible intensity may cause serious undervaluation because of the complexity of the intangible valuation process. It may also reduce debt service capacity since intangibles are not available to collateralize debt in an LBO. We calculate the default probability as our direct 
proxy for financial distress and bankruptcy risk. According to Black and Scholes (1973) and Merton (1974), equity is equivalent to a long position in a call option with strike price equal to the face value of debt while debt is equivalent to a long position on a risk-free bond and a short position in a put option with strike price equal to the face value of debt. Debt holders get paid fully if, and only if, the firm's assets exceed the face value of debt; otherwise, the firm defaults on debt payments and may be forced into liquidation. In bankruptcy, equity holders, as the residual claimants, get paid only after debt holders. Therefore, the probability that firm value does not exceed the face value of debt can be regarded as the default probability.

Specifically, given the standard assumptions underlying the Black-Scholes option pricing formula, the default probability in period $\mathrm{t}$ for a horizon of $T$ years can be calculated as:

$$
P_{T}=N\left[-\frac{\ln \frac{V_{A}}{D}+\left(r-\frac{1}{2} \sigma_{A}^{2}\right) T}{\sigma_{A} \sqrt{T}}\right]
$$

where $N$ is the cumulative normal distribution, $V_{A}$ is the firm's asset value at the calendar year end and $D$ is book value of the total liability of the event firm (and its corresponding matched control firm) before the announcement of the going private deal; $r$ is the annualised contemporary 1-month UK Treasury bill rate; $\sigma_{A}$ is asset volatility. We derive the default probability formula in equation 1 in Appendix A. We also estimate $D$ as book value of short term liability plus half of long term liability, similar to what is suggested in KMV model (see Chan-Lau, 2006) and the empirical results are qualitatively similar. Our measure of $D$ implies a more rigorous estimate of bankruptcy risk.

A related measure of bankruptcy risk is the proximity or distance to default. Distance to default is the number of standard deviations of standard normal distribution that the firm is away from bankruptcy, where the cut-off point for bankruptcy is zero. The cut-off point indicates default, i.e., $\boldsymbol{V}_{\boldsymbol{A}}<\mathrm{D}$. According to Chan-Lau (2006), distance to default is a 
reasonably accurate predictor of corporate defaults ${ }^{1}$. We were able to calculate these bankruptcy risk measures for 199 P2P and 209 control firms.

Control variables. In testing our hypotheses, we also control for other differential characteristics of $\mathrm{P} 2 \mathrm{P}$ targets and control firms based on the motivations for $\mathrm{P} 2 \mathrm{P}$ deals briefly described above. Agency costs of equity: In cash-rich, low-growth or declining sectors, management may be tempted to waste free cash flow through value-destroying investments (Jensen 1986, 1991). The close monitoring by private equity sponsors after going private denies managers such self-indulgence. If this argument holds, going private firms will have a lower growth rate and higher free cash flow than firms not going private. Evidence for the free cash flow hypothesis is mixed. Lehn and Poulsen (1989) and Opler and Titman (1993) provide evidence consistent with the free cash flow hypothesis, but Maupin, Bidwell and Ortegen (1984), Kieschnick (1998), and Servaes (1994) provide contradictory evidence. Neither Halpern et al. (1999) in the US nor Weir, Laing and Wright (2005a) and Renneboog et al (2007) for the UK find that target firms suffer from excessive free cash flow. Halpern et al. (1999) find no impact on P2P likelihood of the lack of growth opportunities but Weir et al. (2005a) find some evidence that P2Ps face lower growth opportunities.

We use operating cash flow to total assets as a proxy for the target's pre-P2P free cash flow. Market value to book value of equity is a proxy for stock market valuation of the target firm's growth opportunities ${ }^{2}$. We excluded negative MTBV observations from the sample, but since only 6 out of our sample of 246 P2P firms have negative MTBVs, our results are robust to exclusion of these observations.

Board (Governance) Mechanisms: If the pre-P2P corporate governance structure is weak, the value gains that result from going private may be large. Private equity sponsors establish small boards with low executive management membership in their investee companies, typically replacing large and inefficient boards (Jensen 1993; Denis, 1994). If 
going private is expected to improve corporate governance and hence shareholder value, we expect a positive relationship between board size and the going private decision. However, a small board may also reflect small firm size and the greater power of executive directors to dominate the boards in these cases. In this event the expected relation is negative.

In the UK, the Cadbury Report and its successor the Combined Code (Cadbury, 1992 and Combined Code, 2003) prescribe splitting the roles of Chief Executive Officer and Chairman of the Board, significant representation for independent directors and the creation of audit and remuneration committees. Boards dominated by powerful Chief Executive Officers who are also Chairmen of Boards i.e. playing a duality of roles, are likely to have been weakly monitored in the pre-P2P period (Baliga, Moyer \& Rao, 1996; Brickley, Lease \& Smith, 1997). Where there is a substantial presence of independent non-executive directors, monitoring is likely to have been strong (Dahya, McConnell \& Travlos, 2002). The presence of audit and remuneration committees provide for more effective monitoring of executive management and management remuneration systems with a high degree of pay-forperformance sensitivity (Klein, 2002; Cohen, Krishnamoorthy \& Wright, 2002). Thus absence of these mechanisms likely contributes to poor performance and undervaluation of the target firm, increasing the probability of a P2P bid. For the UK, Weir et al (2005a) find that UK P2Ps have a higher frequency of duality, while Renneboog et al (2007) report that strong corporate governance monitoring of the pre-P2P target reduces the scope for value creation.

We use several proxies for board (governance) mechanisms. The board size is proxied by the number of directors and the degree of independence in monitoring managers by the proportion of non-executive directors. The ability of the board to monitor is also captured by a variable indicating the presence of audit committees. The dominance of the Chief Executive Officer is measured by a dummy variable capturing the duality of Chief Executive Officer and Chairman of the Board roles. 
Management incentives pre- and post-P2P: Managers with a low ownership stake in the pre-P2P target may see the deal as a way of increasing their ownership due to equitybased incentives and facilitate the $\mathrm{P} 2 \mathrm{P}$ decision. Thus, the probability of going private as well as that of post-P2P value gains is likely to be negatively related to managerial ownership. When managers hold large ownership stakes in the pre-P2P target, they have a strong incentive and the power to promote a transaction from which they will gain immediately in the form of a takeover premium. However, if their large shareholding allows them to secure a favourable post-P2P dispensation in terms of share ownership or executive managerial positions, they might settle for a smaller bid premium. In management buyouts in which the target top managers are part of the acquiring team, this incentive is more compelling. The smaller the pre-P2P shareholding of target directors, the greater is the likely expropriation of gains from other target shareholders. Thus the relationship between probability of a P2P deal and managerial share ownership is a priori difficult to predict.

Halpern (et al., 1999) find for the US that high managerial equity ownership makes a P2P more likely but that the relationship is non-linear. They also show that at both low and high prior managerial equity, the poorer the prior stock performance the higher is the premium received by target shareholders. For the UK, Weir et al (2005a) find that going private firms are more likely to have higher Chief Executive Officer and institutional ownership. Renneboog et al (2007) find that lower managerial shareholding leads to higher gains suggesting that P2Ps provide the opportunity to improve managerial incentives and thereby generate more value for shareholders. Managerial incentives are captured by the percentage of shares held by executive directors. It has been argued that managerial shareholding may promote alignment at low levels but entrenchment at high levels (Morck, Shleifer \& Vishny, 1988, McConnel \& Servaes, 1990). Therefore, following standard practice, we also use the square of executive share ownership to capture this nonlinearity. 
These proxies reflect managerial incentives in the form of managerial stock ownership at the time of the $\mathrm{P} 2 \mathrm{P}$ transaction. Where the $\mathrm{P} 2 \mathrm{P}$ is a management buyout, managerial incentives are strengthened post-P2P. We expect that management buyouts will have a more beneficial impact on reducing bankruptcy risk and firm survival than other types of LBOs such as an management buyin. We use a dummy variable to indicate whether the $\mathrm{P} 2 \mathrm{P}$ is a management buyout.

Regulatory costs for a public corporation: Public listing subjects companies to substantial and costly regulation by stock exchange and other authorities in terms of disclosure, documentation and corporate governance regime. Costs may outweigh benefits even for large, mature firms that have no need to access large risk capital from the stock market (Travlos \& Cornett, 1993). Going private saves these costs (DeAngelo et al, 1984). Travlos and Cornett (1993) for the US market suggest that there is no significant relationship between abnormal returns and relative annual listing costs. For the UK, Renneboog et al (2007) find that high listing costs increase the value gains from P2Ps. Since listing costs are disproportionately high for small rather than large firms because of large fixed components of these costs smaller listed companies are more likely to benefit from going private than large companies. We use a firm size measure, the book value of total assets, as a negative proxy for listing costs.

Stock undervaluation: Information asymmetry between managers and investors results in the undervaluation of the firm in the stock market. Going private eliminates this undervaluation because of the concentrated ownership and control by LBO sponsors (DeAngelo et al., 1984; Jensen, 1991). Managements often argue that their reason for going private is the neglect they have suffered at the hands of investment analysts and investors. Institutional investors may prefer not to invest in small or medium sized firms and some of the undervaluation may be a reflection of the stock market illiquidity caused by this neglect. 
Neglect by analysts and institutional investors may result in stale prices, low trading volume and/or low valuation. The low level of analyst following and lack of institutional investor interest compound the problem of information asymmetry further accentuating the undervaluation problem. Undervalued or underperforming companies are more likely to become takeover targets of predators or other corporate managements who see an opportunity to turn the company around and enhance shareholder value. Managements sometimes use an LBO or P2P as a defensive tactic against hostile takeover bids (Halpern, Kieschnick and Rotenberg, 1999). However, Weir, Laing and Wright (2005a) find no support for P2Ps being triggered by prior hostile takeover bids or takeover rumours.

Renneboog et al (2007) find that one of the main sources of the wealth gains to preP2P shareholders is undervaluation of the pre-transaction target firm. We have two alternative proxies for stock market neglect and the consequent undervaluation. The first is the number of analysts following the $\mathrm{P} 2 \mathrm{P}$ and control firms just prior to the $\mathrm{P} 2 \mathrm{P}$ announcement. The second is a dummy variable equal to 1 where the number of analysts is above the total sample median and 0 if equal to or below that median. A low value of either variable indicates high market neglect. We also include the enterprise value multiple as a measure of target valuation, which is popularly used as a valuation measure in acquisitions, especially in LBOs (Fruhan, 2009). A low value of this ratio indicates that a firm may be undervalued. Enterprise Value is a measure of a company's value, often used as an alternative to straightforward equity market capitalization (market cap). Enterprise value is calculated as market capitalization (of equity) plus debt, minority interest and preferred shares, minus total cash and cash equivalents.

Debt tax benefits and bankruptcy risk: A firm that does not employ leverage up to its optimal level has more to gain from going private since it increases the firm's financial leverage and, therefore, potentially its stock value by increasing the firm's tax shields. Lowenstein (1985) argues that most of the premium paid to target shareholders in LBO deals 
is financed from tax savings. The scope for additional debt related savings would depend on the target's debt (service) capacity. High debt levels in going private LBOs commit cash flows to debt payment (Jensen, 1986). This reduces the free cash flow problem and increases the debt capacity of the post-P2P firm. The lower the pre-P2P debt level, the larger is the debt service capacity. Therefore, we expect to see a positive (negative) relationship between target debt capacity (target leverage) and the going private decision (Kim \& Lyn, 1991).

Halpern et al. (1999) find empirically that high leverage increases the P2P probability but high tax expenditure makes P2P transactions more likely. Renneboog et al. (2007) find for the UK that the increased interest tax shield due to unused debt capacity is one of the main drivers of gains to pre-P2P shareholders. The ratio of debt to total assets (both net of cash) is a balance sheet measure of debt capacity with a low value pointing to high unused debt service capacity and scope for high and beneficial tax shields after the P2P. We employ another, income statement-based proxy earnings before interest, tax, depreciation and amortization to interest costs to measure debt service capacity. This ratio is high when the target is under-leveraged i.e. it has surplus debt service capacity. Another measure of debt capacity is the proportion of tangible assets of the target which can serve as collateral for senior debt raised by LBO firms. We use the ratio of intangible assets to total assets of target firms, as a negative proxy for debt capacity. Appendix B lists all the variables with their definitions.

\section{Methodology}

The option pricing approach to estimating bankruptcy risk and the distance to default of $\mathrm{P} 2 \mathrm{P}$ targets and the control firms was described earlier. We test for the univariate differences in the profiles of P2P targets and their control firms. Both independent sample and non-parametric tests are employed to mitigate the impact of outliers. We then extend our 
analysis of the going private decision using the multivariate logistic regression model. The logistic model estimates the parameters using maximum likelihood methodology. The overall measure of the model fit is given by the Wald Chi-square statistic. This model allows us to assess whether bankruptcy risk significantly impacts on such likelihood (Hypothesis 1).

We then track the target firms, now in the ownership and control of the LBO sponsors, to identify whether or not the sponsors have exited these acquisitions and what the exit routes are. We then examine whether exit through receivership is related to the default probability at going private (Hypothesis 2). We test for the impact of such default probability using a logistic regression model.

\section{RESULTS}

\section{Univariate analysis of factors determining the going private decision}

Table 2 presents the results of univariate analyses of the differences in pre-P2P characteristics of target firms and a control group of same industry firms that remain public companies. Target firms face a significantly higher level of bankruptcy risk with both their mean and median default probability than those firms that stay listed. Similarly, compared to control firms, targets also have significantly shorter distance to default, which means they are more likely to default in one year's time than their matched firms. Targets are significantly slower growing than the control firms in terms of the median sales growth rate. Incumbent managers who join the private equity sponsor in the acquisition may hide the true bankruptcy risk in order to avoid a high acquisition premium. This may be reflected in higher bankruptcy risk in the management buyout deals than in non-management buyout deals. In an unreported univariate test, the difference in default probabilities and distance to default between management buyouts and other types of going-private transactions is statistically insignificant, suggesting no information asymmetries between the managers and the market in our sample. 


\section{\{Insert Table 2 about here\}}

The median enterprise multiple of the going private firm is significantly lower than that of the control firm, indicating that the going private targets might be undervalued. None of the mean differences in debt capacity ratios is significant but median earnings before interest, tax, depreciation and amortization to interest costs is significantly lower than in listed firms. These suggest no greater debt capacity in going private targets. Thus potential tax benefits from using unused debt service capacity may not exist for the going private firms unless post-P2P the performance of the target firms improves. There is strong evidence that targets have much lower price earnings multiples than the other listed firms. They also have much lower market to book value multiples although in this case only the median differences are significant. The median enterprise value multiple of the targets is also significantly smaller. These ratio differences support the undervaluation proposition. Also, the firm size (measured by book value of total assets) of the P2P firms is significantly smaller than that of the control firms. This is consistent with the imperfect nature of our size control in the selection of our control firms (see our earlier discussion of the construction of the control sample). Given this inadequate size control, some difference in the size dispersion of the P2P and control samples is to be expected.

However, targets are no different from control firms in their intangible asset intensity. There is strong evidence that target firms have suffered market neglect. While the average (median) number of analysts following the listed firms is 6.9 (4.0), the corresponding number for the target firms is 3.6 (2.0). The mean and median differences are both strongly significant at the $1 \%$ level. With the analyst dummy variable as a proxy for market neglect, we find similar and equally significant differences in analyst following.

There is evidence that going private firms have significantly smaller boards but there is no significant difference in the proportion of non-executive directors between the two 
groups. $16 \%$ of the targets firms have duality of executives while $17 \%$ of control firms have duality of executives with the difference being insignificant. $93 \%$ of both groups have audit committees. The differences in median and mean executive director's shareholdings between going private firms and non-going private firms are insignificant.

Overall, the univariate analysis provides significant support for our hypothesis H1 that P2P targets face higher bankruptcy risk than non-targets. The analysis also supports the view that market undervaluation and market neglect factors motivate $\mathrm{P} 2 \mathrm{P}$ deals. The undervaluation may be partly attributable to the poorer operating performance, slower growth of the target firms and greater bankruptcy risk they face. But the observed undervaluation may also be due to the greater market neglect of these firms. There is some evidence of an efficient corporate governance structure, i.e. smaller boards. But there is no unambiguous indication of governance failure in target firms. There is no evidence of greater debt capacity.

We also estimated the skewness and kurtosis of the distance-to-default and probability of default variables. While both these variables are positively skewed, distance to default has a less severe skewness (1.63) than probability of default (10.63). Similarly, estimates of the kurtosis of these two variables indicate that the sample probability of default suffers a more severe fat-tails problem with a kurtosis value of 137.92 while the kurtosis of the distance to default variable is 3.98 . Thus the distance to default variable has a more normal statistical distribution making it a more appealing variable for our subsequent analyses.

In Table 3, we further study the range of default probabilities associated with the credit quality embodied in Moody's rating categories. Table 3 also provides further Moody's rating categories and our classification of sample firms. One basis point (bp) equals 0.0001 . The Moody's KMV model expresses default probability in basis points. According to Moody's KMV model, firms with default probability lower than 2 basis points (bps) are highly unlikely to go bankrupt within one year ${ }^{3}$ (Chan-Lau, 2006). Aaa rated firms fall in this 
category. The minimum investment grade rating is Baa and corresponds to a default probability of 20 basis points or less. We may regard firms with default probability higher than 400 basis points as the firms that are extremely likely to go bankrupt within one year. Ca rated firms fall in this group including, 20 out of 199 of our sample firms. 52 target firms in our sample fall into sub-investment grade (junk bond) categories indicating that their borrowing costs are likely to be very high.

\section{\{Insert Table 3 about here}

\section{Results of multivariate analysis of target characteristics}

We run multivariate logistic regression models to identify the determinants of the going private decision. Some of the explanatory variables listed in Table 2 are not included in the initial model reported in Table 4 but their impact on the models is discussed below. We also include year dummies to account for the time factor on the going private decision. The unreported coefficients of the year dummies are statistically insignificant indicating that the odds of going private do not vary across the sample years.

The full model (Model 2) is overall significant at the $1 \%$ level. We tested for multicollinearity using the standard approach of examiningvariance inflation factor (VIF) statistics (see Gujarati, 2003, pp362-3). This factor for all the variables is about 2 or less except with EXECSHARE ${ }^{2}$ and EXECSHARE for obvious reasons. For these two variables VIF is about 10 which is the level above which collinearity becomes a moderately serious problem. Thus our model is quite robust to multicollinearity.

\section{\{Insert Table 4 about here $\}$}

The results show that companies with higher bankruptcy risk are more likely to go private, consistent with the univariate analysis results. According to Table 4, one standard deviation increase in distance to default decreases the odds of going private by $19 \%$ (Model 2). This supports our hypothesis $H 1$. 
Highly leveraged firms are less likely to go private, probably because they have little unused debt capacity. This result seems to contradict the result on default probability since a high leverage firm is more likely to default. We also find support for market neglect as an incentive for going private. The smaller the number of analysts that follow the target, the greater is the likelihood of going private. Firms with higher managerial shareholding are more likely to go private. However, it has a diminishing marginal impact as the coefficient of the squared executive share variable is significantly negative. The percentage of non-executive directors on the board is also related positively to the likelihood of going private. The impact of other corporate governance mechanisms including board size, duality and audit committee, is insignificant. The P2P bids seem driven primarily by higher bankruptcy risk, greater market neglect, and higher managerial incentives from stock ownership, and greater board independence of the target firms than in firms that remain public companies.

In unreported analysis, we also ran another logistic regression with executive share ownership as a simple linear term and with the free cash flow variable. In this model, again distance to default and executive share ownership are significant with the same signs on the coefficients. Overall, bankruptcy risk remains a significant factor, robust to different model specifications.

\section{Bankruptcy risk and subsequent bankruptcy}

High bankruptcy risk that provides LBO sponsors with the challenging opportunity to create value through turnaround is shown by our preceding analysis as a major determinant of the going private decision. Given this evidence, the question arises about the fate of these high risk investments. Do they end up in actual bankruptcy? If so, we can expect a significant relationship between the default probability or distance to default at the going private stage and eventual exit by the LBO sponsor through bankruptcy. In the next stage of our analysis, we follow up the completed deals and track their exit mode using the CMBOR database. 
Specifically, we classify exit mode into five distinct categories, i.e. bankruptcy or receivership, flotation (Initial Public Offering) on a stock market, trade sale to a corporate buyer, secondary buyout via, say, management buyout or management buyin to another private equity firm, and None, where None indicates no exit i.e. the targets are still held in the sponsor's portfolio.

Panel A of Table 5 shows the holding period of the targets by the LBO investors. In the case of no exit, we calculate the holding period of these firms till the end of 2005. For firms going private in 2004 and 2005 the holding period is biased downwards because of this cut off date compared to earlier deals in our sample. There are no significant differences in holding periods across different exit modes. Panel B of Table 5 classifies the default probability and distance to default into the five aforementioned categories. Out of the 10 receivership cases, we are unable to calculate the default probability for 1 case due to the unavailability of related accounting data.

As expected, the targets that end up in receivership as exit mode have the highest default probability at the time of the $\mathrm{P} 2 \mathrm{P}$, amounting on average to 376 basis points (highest probability) and on average 2.76 standard deviations to the default threshold (shortest distance). Firms still retained within the LBO sponsor's portfolio i.e. in the None group have a low mean default probability and are a long way from default. Firms exited through trade sale or secondary buyouts are on average very healthy firms with zero median default probabilities. In Panel $\mathrm{C}$ of Table 5, we examine the default probability of the nine target firms that end up in receivership. There are two extreme cases which have default probability more than $10 \%$ percent (over 1000 basis points). Further, five of the nine target firms have probability of default of 72.71 basis points and above, well above the threshold of 20 basis points for subinvestment grade rating (see Table 3 and discussion of our robustness analysis below). This indicates that our default probability measures have fair predictive ability. 


\section{\{Insert Table 5 about here\}}

We also track the exit mode of the targets with high default probability in Table 6. As shown in that table over the sample period, 2 out of 18 targets that have default probability over 400 basis points end up in bankruptcy. As reported in Table 3, there are 20 targets with default probability higher than 400 basis points. We are only reporting 18 cases in Table 8 because the exit mode information of 2 targets is unavailable. There are 2 cases of initial public offerings and 1 case of trade sale. Most of the targets, however, are still held by the LBO sponsors. It is not clear whether the continued holding of these investments is voluntary because they have been turned around or involuntary because the LBO sponsors are 'nursing' them in intensive care and are loath to declare their demise.

As a robustness test, we further look at the exit mode of the targets that have default probability higher than 20 basis points (equivalent to Moody's ratings below Baa). Rating below this level is sub-investment or junk bond rating. In addition to the 2 bankruptcy cases discussed above, we identify another 3 targets that exit by receivership. Thus 5 out of 52 (about $10 \%$ of) targets with junk rating before the P2P buyout go bust. Four targets (out of 147 or $2.7 \%$ ) with higher credit rating also end up in receivership. See Table 3 for the mapping of default probabilities to Moody's rating categories.

\section{\{Insert Table 6 about here\}}

Further, in Table 7, we report the results of logistic regressions to study the determinants of the probability of the targets exiting through receivership. In Model 1, distance to default has significant explanatory power as regards the receivership exit mode. In Model 2, which is overall insignificant, distance to default still holds strong explanatory power for the receivership exit mode. In both models this variable is significant at the 5\% level. P2P targets with a high bankruptcy risk are more likely to go bankrupt under private equity ownership. 
This supports our hypothesis $\mathrm{H} 2$ and suggests that the turnaround capabilities of private equity firms are not adequate to turn around these very distressed firms. Higher debt capacity (as indicated by the ratio of earnings before interest, tax, depreciation and amortization to interest costs) before going private is associated with higher probability of ending up in receivership. We conjecture that private equity sponsors overexploit the high debt capacity and push the leverage too high. Regarding corporate governance, independent target boards i.e. targets with a higher proportion of non-executive directors before going private face shorter odds of exit through receivership. P2P target firms bought out through a management buyout are less likely to go bust after the deal. Since management buyouts promote greater alignment between managers and LBO sponsors, this result is consistent with reduced agency problems allowing more enhanced performance and reduced bankruptcy risk.

\section{\{Insert Table 7 about here $\}$}

\section{SUMMARY AND CONCLUSIONS}

The primary focus of this paper is whether bankruptcy avoidance is a significant motive for listed companies to go private. By the same token, do LBO sponsors buy targets facing high bankruptcy risk in the hope of exploiting the opportunity for turnaround and substantial upside gains? We study the exit mode of the going private deals, in particular, through bankruptcy and how bankruptcy risk impacts on the exit mode.

For a sample of 246 going private acquisitions completed in the UK during 19972005, almost the entire population, we find, in contrast to Opler and Titman (1993) in the US, that bankruptcy risk does not deter private equity firms from P2P deals. Indeed, we find that such risk raises the chances of a P2P buyout. Private equity acquirers seem to regard target's poor performance and, in many cases financial distress, as a turnaround opportunity. In this research, we find that going private firms are less valued, smaller and suffer from lower growth than firms in the same industries that remain public companies, consistent with US 
evidence. We also find new evidence that greater market neglect in the form of low analysts' following contributes to the going private decision. We find evidence that top management shareholding has a significant, and nonlinear, impact on the going private decision.

We investigate whether high bankruptcy risk at the time of the $\mathrm{P} 2 \mathrm{P}$ transaction dooms the acquisition to subsequent failure. We find evidence that high receivership risk at going private increases the chance that the target will end up in receivership. In such cases the turnaround efforts of the LBO sponsors seem to have failed. Targets of going private deals which the LBO sponsors exit subsequently through bankruptcy exhibit a very high bankruptcy risk at the time of going private but post-LBO bankruptcy likelihood is less when the LBO is a management buyout rather than any other form of buyout. This evidence points to the importance of managerial interests being aligned to the sponsors' interests. We also find that independent boards of pre-P2P targets promote going private deals and reduce the chances of bankruptcy after the buyout. Thus a good corporate governance structure seems to make a positive contribution to bankruptcy avoidance after going private transactions. Although, due to the small number of receivership exits in our sample of P2P firms, the results are not as strong as we would like, a more extended analysis involving a larger sample over a longer period, in particular of firms exiting through bankruptcy is expected to produce stronger results. Our results provide a sufficient basis to warrant such further analysis.

\section{Limitations and further research}

As all studies, this article has a number of limitations that provide opportunities for further research. This study has investigated only some of the possible motivations in going private transactions. Other motivations, such as that of shareholder-aligned managers of target firms to transfer wealth from lenders (Travlos \& Cornett, 1993) or that of the private equity buyer to exploit the tax advantages of debt to the benefit of its equity investors thereby transferring 
wealth from government to equity investors (Lowenstein, 1985), are areas for further research.

We have investigated one aspect of post-P2P performance - the exit into bankruptcy. Other aspects of post-P2P performance and the factors that contribute to enhanced performance and turn around need researching. Post-P2P performance analysis is important to bring insights concerning the benefits of going-private transactions and would also help to answer the question whether the same benefits could be achieved without going private.

As a result of data limitations arising from these firms becoming private companies, we have not examined the extent and nature of post-buyout restructuring activities. One potentially important issue relates to post-buyout divestment of activities, which have been identified as a consequence of the governance arrangements in private equity backed buyouts leading to successful exits (Nikoskelainen \& Wright, 2007). A particularly interesting issue that arises here is to what extent private equity firms break up distressed firms by selling off assets piecemeal at a premium to leave a rump of loss making assets that can be placed into receivership.

A potentially important issue concerns the distinction between the selection and value creating abilities of private equity firms. For example, certain firms (with certain characteristics) could be considered to be easier P2P targets than others, which would suggest that targets are a non-random choice. Further, more fine-grained research is needed to examine this issue. In addition, more fine-grained analysis of the prior experience of the private equity firms in dealing with problem cases could also be undertaken in future studies.

Although we identified a positive role for non-executive directors in determining whether P2Ps with high bankruptcy risk occurred, it was beyond the scope of this paper to examine the acquisition process. Recent studies have pointed to the distinction between the public operation of the market for corporate control and the role of private auctions and 
negotiations in the sale of listed corporations (Boone \& Mulherin, 2007; Wright, Weir \& Burrow, 2007). Further interesting insights may be obtained by examining the acquisition process involving private equity backed $\mathrm{P} 2 \mathrm{Ps}$ of listed corporations with high bankruptcy risk.

A further governance aspect that was beyond the scope of this study is to examine the process by which private equity firms attempt to reduce bankruptcy risk post-buyout. One particular dimension of this process concerns the need to examine how the actions taken by private equity firms to avoid placing the firm into the bankruptcy process through cost reductions, debt for equity swaps, renegotiations of bank covenants, etc. are more timely and effective than the actions taken by the boards in listed corporations. A contrasting concern relating to the governance effects of private equity firms which warrants further examination is the extent to which they 'cash out' through special dividends, share buy-backs and management fees paid by target firms post-P2P, which are financed by increased leverage thereby weakening the target firms' financial position and increasing bankruptcy (Sudarsanam, 2010, Ch.11).

The study has relied on data on UK P2Ps, but P2Ps are now a worldwide phenomenon. Different institutional contexts involve different bankruptcy regimes as part of the overall corporate governance context (Davydenko \& Franks, 2008). Further research might usefully examine the extent to which differences occur in these regimes in the bankruptcy risks associated with P2Ps.

We also acknowledge methodological points relating to our treatment of DD. First, as DD may not fully recognize risk because the asset values are not allowed to be discontinuous we assume that asset value follows a geometric Brownian motion process. An alternative would be to use a Levy process but this is very complex to model and seems to us to be beyond the scope of this paper which is focused on corporate governance aspects. We have followed a simple but widely used model but modelling discontinuity in a more fine-grained 
way is an area for future research. Second, we recognize that DD is not a perfect measure of bankruptcy risk. Further research may be able to extend our measure of DD by more recent accounting data on firm liabilities and more accurate valuation of firm's assets. Third, our focus here is on individual company level bankruptcy risk but in the recent credit crisis period there have also been macro-concerns about the systemic risk impact of $\mathrm{P} 2 \mathrm{P}$ deals. Future research may seek to extend our work to assess bankruptcy risk at a sectoral level. Such analysis is beyond the scope of this study but would need to be aware that simply aggregating individual firms' balance sheets and equity market values may produce average default risks that are not representative of systemic default risk in the system and may need to adopt alternative approaches (see e.g. Tudela and Young, 2005).

\section{Implications for practice and policy}

Private equity backed P2Ps involving distressed firms add to the market for corporate control in two ways. First, the threat of a P2P may of itself place pressure on management and boards to address performance problems. Second, the completion of such acquisitions provides an alternative to traditional acquirers who may be unwilling to acquire problem or distressed corporations. Private equity backed P2Ps, by bringing in better governance, may provide opportunities for salvaging companies that might otherwise fail.

Our finding of reduced bankruptcy risk post-P2P in the case of management buyouts adds to the limited literature that stresses the importance to private equity firms of having access to insider knowledge from incumbents about the business. Although private equity firms will conduct due diligence prior to investment, in publicly listed corporations this may be incomplete. Hence our findings suggest that private equity firms contemplating buyouts of distressed firms should aim to keep at least some of the incumbent management team on board as part of the deal, since these insiders are likely to be aware of where the problems lie. 
Our finding that independent boards pre-P2P reduce bankruptcy risk post-P2P provides an important practical insight that adds to existing knowledge regarding the role of good corporate governance mechanisms in effecting restructuring activity (Hoskisson, Johnson \& Moesel, 1994). Good corporate governance can mean that boards make timely decisions to sell the firm to a private equity firm at a price that maximizes value for outgoing shareholders but which also means that problems can be addressed by private equity acquirers before they have become too entrenched. For listed corporations, therefore, our findings suggest that strengthening of independent boards may contribute to timely decisions to sell troubled corporations.

\section{Conclusions}

The role of private equity backed buyouts as an alternative to the governance mechanism found in listed corporations is the subject of considerable debate. Using a unique handcollected dataset of public to private buyouts we provide, in contrast to prior research, novel evidence that private equity firms can augment the market for corporate control in acquiring troubled corporations. However, our finding that public to private deals with a higher initial bankruptcy risk are more likely to enter receivership is a reason for caution in claims about the superiority of private equity governance model in these cases but also highlights the risky nature of $\mathrm{P} 2 \mathrm{P}$ deals when the motivation is the turnaround opportunity. 


\section{References}

Baliga, B. R., Moyer, R.C., \& Rao, R.S. 1996. CEO duality and firm performance: what's the fuss? Strategic Management Journal, 17: 41-53.

Black, F. \& Scholes, M. 1973. The pricing of options and corporate liabilities. Journal of Political Economy, 81: 637-654.

Boone, A. \& Mulherin, H. 2007. How are firms sold? Journal of Finance, 62(2):847-875.

Brickley, J., Lease R. \& Smith, C. W. 1998. Ownership structure and voting on antitakeover amendments. Journal of Financial Economics, 20: 267-291.

Cadbury, A. 1992. Cadbury Report: the Financial Aspects of Corporate Governance. London: Financial Reporting Council, United Kingdom.

Cariboni, J. \& Schoutens, W. 2007. Pricing credit default swaps under Levy models, Journal of Computational Finance, 10.

Chan-Lau, J. A. 2006. Market-based estimation of default probabilities and its application to financial market surveillance. IMF working paper.

Chan-Lau, J. A. \& Gravelle, T. 2005. The END: A New Indicator of Financial and Nonfinancial Corporate Sector Vulnerability, IMF working Paper, WP/05/231.

Citron, D., Wright, M., Rippington, F. \& Ball, R. 2006. Bankruptcy costs, leverage and multiple secured creditors: the case of MBOs. Paper presented at the Multinational Finance Conference, Edinburgh, June.

CMBOR 2009. The UK buy-out market. Management Buy-outs: Quarterly Review from CMBOR. CMBOR: University of Nottingham.

Cohen J., Krishnamoorthy, G. \& Wright, A.M. 2002. Corporate governance and the audit process. Contemporary Accounting Research, 19: 573-94.

Cressy, R., Malipiero, A. \& Munari, F. 2007. Playing to their strengths? Evidence that 
specialization in the private equity industry confers competitive advantage. Journal of Corporate Finance, 13: 647-669.

Cumming, D., Siegel, D. \& Wright, M. 2007. Private equity, leveraged buy-outs and governance. Journal of Corporate Finance, 13: 439-460.

Dahya, J., McConnell, J.J. \& Travlos, N.G. 2002. The Cadbury Committee, corporate performance and top management turnover. Journal of Finance, 57: 461-83.

Davydenko, S. \& Franks, J. 2008. Do bankruptcy codes matter? A study of defaults in France, Germany and the UK. Journal of Finance, 63 (2): 565-608.

DeAngelo, H. \& DeAngelo, L. 1987. Management buyouts of publicly traded corporations. Financial Analysis Journal, 43: 38-49.

DeAngelo H., DeAngelo, L. \& Rice, E. 1984. Shareholder wealth and going private. Journal of Law and Economics, 27: 367-402.

Denis, D. 1992. Corporate investment decisions and corporate control: Evidence from going -private transactions. Financial Management, 21: 80-94.

Denis, D. 1994. Organizational form and the consequences of highly leveraged transactions, Kroger's recapitalization and Safeway's LBO. Journal of Financial Economics, 36: 193-224.

Fama, E. \& Jensen, M. 1983. Separation of ownership and control. Journal of Law and Economics, 26: 301-349.

Financial Services Authority. 2003. The Combined Code on Corporate Governance. London: Financial Services Authority, United Kingdom.

Financial Services Authority. 2006. Private equity: a discussion of risk and regulatory engagement. Discussion Paper DP06/6. London: Financial Services Authority.

Frankfurter, G. M. \& Gunay, E. 1992. Management buy-out: The sources and sharing of 
wealth between insider and outsider shareholders. Quarterly Review of Economics and Finance, 32: 82-95.

Fruhan, W. 2009. The role of private equity firms in merger and acquisition transactions.

\section{Harvard Business School case 9-206-101.}

Gujarati, D. 2003. Basic Econometrics, New York:McGraw Hill.

Guo, S., Hotchkiss, E. \& Song, W. 2010. Do buyouts (Still) create value? Journal of Finance (forthcoming).

Halpern, P., Kieschnick, R. \& Rotenberg, W. 1999. On the heterogeneity of leveraged going private transactions. The Review of Financial Studies, 12: 281-309.

Hillegeist, S. A., Keating, E.K., Cram, D.P. \& Lundstedt, K.G. 2004. Assessing the probability of bankruptcy. Review of Accounting Studies, 9: 5-34.

Hoskisson, R.E., Johnson, R.A. \& Moesel, D.D. 1994. Corporate divestiture intensity in restructuring firms: Effects of governance, strategy and performance. Academy of Management Journal, 37(5): 1207-1251.

Jensen, M. \& Meckling, W. 1976. Theory of the firm: Managerial behavior, agency cost, and ownership structure. Journal of Financial Economics, 3: 305-360.

Jensen, M. 1986. Agency costs of free cash flow, corporate finance and takeovers. American Economic Review, 76: 323-329.

Jensen, M. 1989. The eclipse of the modern corporation. Harvard Business Review, 67: 61-74.

Jensen, M. 1991. Corporate control and the politics of finance. Journal of Applied Corporate Finance, 4: 13-33.

Jensen, M. 1993. The modern industrial revolution: Exit, and the failure of internal control systems. Journal of Finance, 48: 831-880.

Kaplan, S. 1989. The effects of management buyouts on operating performance and value. Journal of Financial Economics, 24: 217-54. 
Kaplan, S. \& Stromberg, P. 2008. Leveraged buy-outs and private equity. Journal of Economic Perspectives, 23: 121-46.

Kieschnick, R. 1998. Free cash flow and stockholder gains in going private transactions revisited. Journal of Business Finance and Accounting, 25: 187-202.

Kim, W. \& Sorensen, R. 1986. Evidence on the impact of agency cost of debt on corporate debt policy. Journal of Financial and Quantitative Analysis, 21: 131-144.

Kim, W. S. \& Lyn, E. 1991. Going private: Corporate restructuring under information asymmetry and agency problems. Journal of Business Finance and Accounting, 18: 637-648.

Klein, A. 2002. Audit committee, board of director characteristics and earnings management. Journal of Accounting and Economics, 33: 375-400.

Lehn, K. \& Poulsen, A. 1989. Free cash flow and stockholder gains in going private transactions. Journal of Finance, 44: 771-788.

Lipton, A. 2002. Asset with Jumps, Risk, September, 149-153.

Lowenstein, L. 1985. Management buyouts. Columbia Law Review, 85: 730-784.

Madan, D. \& Schoutens, W. 2008. Break on through to the single side, Journal of Credit Risk, 4 (3): 3-20.

Marais, L., Schipper, K. \& Smith, A. 1989. Wealth effects of going private for senior securities. Journal of Financial Economics, 23: 155-191.

Maupin, R., Bidwell, C. \& Ortegren, A. 1984. An empirical investigation of the characteristics of publicly-held corporations that change to private ownership via management buyouts. Journal of Business Finance and Accounting, 11: 345-359.

McConnell, J. \& Servaes, H. 1990. Additional evidence on equity ownership and corporate value. Journal of Financial Economics, 27: 595-612.

Merton, R. C. 1974. On the pricing of corporate debt: The risk structure of interest rates. 
Journal of Finance, 29: 449-470.

Morck, R., Shleifer, A. \& Vishny, R. 1988. Characteristics of targets and friendly takeovers, in A Auerbach (ed); Corporate takeovers: Causes and consequences, Chicago: University of Chicago Press.

Nikoskelainen, E. \& Wright, M. 2007. The impact of corporate governance mechanisms on value increase in leverage buyouts. Journal of Corporate Finance, 13(4): 511-537.

Opler, T. \& Titman, S. 1993. The determinants of leveraged buyout activity: Free cash flow vs. financial distress costs. Journal of Finance, XLVIII: 1985-1999.

Palepu, K. 1985. Predicting takeover targets: A methodological and empirical analysis. Journal of Accounting and Economics, 8: 3-35.

Renneboog, L., Simons, T. \& Wright, M. 2007. Why do public firms go private in the UK? The impact of private equity investors, incentive alignment and undervaluation. Journal of Corporate Finance, 13(4): 591-628.

Servaes, H. 1994. Do takeover targets overinvest? Review of Financial Studies, 7: 253-277.

Strömberg, P. 2008. The new demography of private equity. In Lerner, Josh. \& Gurung, A.(eds). The Global Impact of Private Equity Report 2008, Globalization of Alternative Investments, Working Papers Volume 1, 3-26, Davos: World Economic Forum.

Sudarsanam, S. 2010. Creating value from mergers and acquisitions: The challenges, (Harlow: FT Prentice Hall), $2^{\text {nd }}$ edition

Travlos, N. \& Cornett, M. 1993. Going private buy-outs and determinants of shareholders' returns. Journal of Accounting, Auditing and Finance, 8: 1-25.

Treasury Select Committee.2006. Tenth Report,http://www.parliament.the-stationeryoffice.com/pa/cm200607/cmselect/cmtreasy/567/56702.htm).

Tudela, M. \& Young, G. 2005. A Merton model approach to assessing the default risk of UK 
public companies. International Journal of Theoretical and Applied Finance, 8(06): 737-761.

Weir, C., Laing, D. \& Wright, M. 2005a. Incentive effects, monitoring mechanisms and the threat from the market for corporate control: an analysis of the factors affecting public to private transactions in the UK. Journal of Business Finance \& Accounting, 32: 909-944.

Weir, C., Laing, D. \& Wright, M. 2005b. Undervaluation, private information, agency costs and the decision to go private. Applied Financial Economics, 15: 947-961.

Wilson, N., Wright, M. \& Altanlar, A. 2009. Private equity, buy-outs, leverage and failure, University of Leeds working paper.

Wright, M., Renneboog, L., Simons, T. \& Scholes, L. 2006. Leveraged buyouts in the UK and Continental Europe. Journal of Applied Corporate Finance, 18: 38-55.

Wright, M., Amess, K., Weir, C. \& Girma, S. 2009. Private equity and corporate governance: retrospect and prospect. Corporate Governance: An International Review, 17: 253375. 


\section{Appendix A: Estimation of Default Probability}

Following option pricing theory (Black-Scholes and Merton?), we assume that firm's asset value follows stochastic process:

$$
d V_{A}=\mu V_{A} d t+\sigma_{A} V_{A} d W_{t}
$$

where $V_{A}$ and $d V_{A}$ are the firm's asset value and change in asset value respectively; $\mu$, and $\sigma_{A}$ are the firm's asset value drift rate and volatility; $d W_{t}$ is a Wiener process. We calculate the default probability, $P_{T}$ by T, as the probability that the market value of the firm's assets value will be less than the face value of the firm's liability by the time the debt matures, i.e., time $T$. This can be expressed as:

$$
\left.\left.P_{T}=\operatorname{Pr}\left|V_{A} \leq D\right| V_{A}^{0}=V_{A}\right\rfloor=\operatorname{Pr}\left|\ln V_{A} \leq \ln D\right| V_{A}^{0}=V_{A}\right\rfloor
$$

where $V_{A}$ is the current market value of assets; and $D$ the face value of the firm's total liabilities due at time $T$; and

$$
V_{A}^{T}=V_{A} \exp \left[\left(\mu-\frac{1}{2} \sigma_{A}^{2}\right) T+\sigma_{A} \sqrt{T} z\right]
$$

where $\mu$ is the expected return on firm assets and $z$ its random component following a normal distribution with zero mean and unit variance. After log transformation, we have

$$
\ln V_{A}^{T}=\ln V_{A}+\left(\mu-\frac{1}{2} \sigma_{A}^{2}\right) T+\sigma_{A} \sqrt{T} z
$$

Substituting equation A.4 into equation A.2 and re-arranging, we obtain:

$$
P_{T}=\operatorname{Pr}\left[-\frac{\ln \frac{V_{A}}{D}+\left(\mu-\frac{\sigma_{A}^{2}}{2}\right) T}{\sigma_{A} \sqrt{T}} \geq z\right]
$$

Following Black and Scholes (1973) and assuming $z$, is normally distributed, $z \sim N(0,1)$. the default probability is: 


$$
P_{T}=N\left[-\frac{\ln \frac{V_{A}}{D}+\left(\mu-\frac{1}{2} \sigma_{A}^{2}\right) T}{\sigma_{A} \sqrt{T}}\right]
$$

Note that the term within the parentheses of equation A.7 is the distance-to-default, which is the number of standard deviations that the firm is away from default level.

The estimation of distance to default and $P_{T}$ requires the knowledge of the firm's assets value and firm's assets volatility, which are not directly observable. Crosbie and Bohn (2005) suggest solving a non-linear two equations system simultaneously to estimate $V_{A}$ and $\sigma_{A}$. Since, equity value is equivalent to a long position on a call option with strike price equals to the face value of debt (Merton, 1974), we have:

where $d_{1}=\frac{\ln \frac{V_{A}}{D}+\left(r+\frac{\sigma_{A}^{2}}{2}\right) T}{\sigma_{A} \sqrt{T}}, d_{2}=\frac{\ln \frac{V_{A}}{D}+\left(r-\frac{\sigma_{A}^{2}}{2}\right) T}{\sigma_{A} \sqrt{T}}$, and $\mathrm{r}$ is the risk free rate.

$$
V_{E}=V_{A} N\left(d_{1}\right)-D e^{-r T} N\left(d_{2}\right)
$$

Equity and asset volatility are related by the following equation:

$$
\sigma_{E}=\frac{V_{A}}{V_{E}} N\left(d_{1}\right) \sigma_{A}
$$

We implement the Gauss-Seidel iteration technique in solving the non-linear equations system (A.7 and A.8).

We measure $V_{E}$ as the market capitalization of the going private target at the end of the calendar year immediate before announcement of the going private deal. $\sigma_{E}$ is the stock prices volatility during the calendar year prior to the going private deal. $r$ is the annualized contemporary 1-month Treasury Bill rate. We employ alternative measures of debt. Specifically, we use book value of total liability as the main measure of $D$. We also use total debt, (total debt + short term liabilities - cash on balance sheet), and (short term 
1

2

3

4

5

6

7

8

9

10

11

12

13

14

15

16

17

18

19

20

21

22

23

24

25

26

27

28

29

30

31

32

33

34

35

36

37

38

39

40

41

42

43

44

45

46

47

48

49

50

51

52

53

54

55

56

57

58

59

60

liabilities + half long term liabilities) as alternative measures. Similar to $V_{E}, D$ is measured at the end of calendar year immediate before the announcement of the going private deal. Finally, according to common practice, (Hillegeist et al., 2004; and ChanLau, 2006), we set $T$ to 1 in our calculation to estimate the default probability of the firm in one year time. 


\section{Appendix B Definitions of explanatory variables}

\section{See section 3 for details on the data sources.}

\begin{tabular}{|c|c|}
\hline Variables & efinitions \\
\hline robability & $\begin{array}{l}\text { Default probability based on market data. According to Merton (1974), the } \\
\text { default probability of a particular firm in period t for a horizon of } \mathrm{T} \text { years can } \\
\text { be calculated as } P_{T}=N\left[-\frac{\ln \frac{V_{A}}{D}+\left(\mu-\frac{1}{2} \sigma_{A}^{2}\right) T}{\sigma_{A} \sqrt{T}}\right] \text { where } \mathrm{N} \text { is the } \\
\text { cumulative normal distribution, } \mathrm{V}_{\mathrm{A}} \text { is the current assets value, } \mathrm{D} \text { is the book } \\
\text { value of total liabilities or debt, } \mathrm{r} \text { is the risk-free rate, and } \sigma_{\mathrm{A}} \text { is the asset } \\
\text { volatility. (See Appendix A for the details) }\end{array}$ \\
\hline Distance to Default & $\begin{array}{l}\text { Distance to default, }\left[-\frac{\ln \frac{V_{A}}{D}+\left(\mu-\frac{1}{2} \sigma_{A}^{2}\right) T}{\sigma_{A} \sqrt{T}}\right] \text {, used as an alternative } \\
\text { proxy for financial distress is the number of standard deviations of the } \\
\text { standard normal distribution that the firm is away from bankruptcy, where the } \\
\text { cut-off point for bankruptcy is zero. }\end{array}$ \\
\hline Operating cash flow & $\begin{array}{l}\text { Average of the ratios of operating cash flow (fund from operation) over total } \\
\text { assets } 3 \text { years prior to P2P from the three most recent annual accounting } \\
\text { statements }\end{array}$ \\
\hline $\begin{array}{l}\text { Enterprise value to } \\
\text { earnings }\end{array}$ & $\begin{array}{l}\text { Enterprise value over earnings before interest, tax, depreciation and } \\
\text { amortization in the accounting year prior to } \mathrm{P} 2 \mathrm{P} \text { announcement. Enterprise } \\
\text { value is estimated by the formula: market capitalization at fiscal year end date } \\
+ \text { preferred stock + total debt minus cash }\end{array}$ \\
\hline Debt to total assets & $\begin{array}{l}\text { Total debt (net of cash) over total assets (net of cash) in the accounting year } \\
\text { prior to going private }\end{array}$ \\
\hline $\begin{array}{l}\text { Earnings before interes } \\
\text { etc. }\end{array}$ & $\begin{array}{l}\text { Earnings before interest, etc. tax, depreciation and amortization divided b } \\
\text { interest expense in the accounting year prior to } \mathrm{P} 2 \mathrm{P} \text { announcement }\end{array}$ \\
\hline
\end{tabular}


Table 1: Descriptive statistics for the P2P sample

The sample comprises of 246 UK going private deals from 1997 to 2005 . A management buyout involves the top managers of a target business as equity investors with the private equity firm in the acquisition vehicle.

\begin{tabular}{|c|c|c|c|c|c|}
\hline \multicolumn{6}{|c|}{ Panel A: P2P transaction value by year } \\
\hline Year & Observations & Mean (£ M) & Median (£M) & Std. $(\mathfrak{E} M)$ & Total $(\mathfrak{E}$ M) \\
\hline 1997 & 7 & 55.74 & 35.90 & 45.12 & 390.20 \\
\hline 1998 & 26 & 97.09 & 27.05 & 207.37 & 2524.39 \\
\hline 1999 & 44 & 104.84 & 49.00 & 159.06 & 4613.05 \\
\hline 2000 & 41 & 213.07 & 59.60 & 571.69 & 8735.84 \\
\hline 2001 & 32 & 152.79 & 78.43 & 187.38 & 4889.40 \\
\hline 2002 & 22 & 122.31 & 23.14 & 227.37 & 2690.83 \\
\hline 2003 & 35 & 109.49 & 18.70 & 299.72 & 3832.32 \\
\hline 2004 & 19 & 184.11 & 26.46 & 279.80 & 3498.18 \\
\hline 2005 & 20 & 361.38 & 167.50 & 430.74 & 7227.65 \\
\hline Total & 246 & 156.11 & 47.70 & 330.62 & 38401.86 \\
\hline \multicolumn{6}{|c|}{ Panel B: P2P Transaction value by deal type } \\
\hline & Observations & Mean $(£$ M) & Median (£M) & Std. $(\mathfrak{f} M)$ & Total $(£$ M) \\
\hline $\mathrm{MBO}$ & 99 & 212.75 & 59.3 & 442.90 & 21062.25 \\
\hline NonMBO & 147 & 117.95 & 43.75 & 253.06 & 17339.61 \\
\hline
\end{tabular}

- 7 - 
-8 - 


\section{Table 2: Descriptive statistics}

The table reports the t-test ( $\mathrm{t}$ value) and Wilcoxon ranked sums test ( $\mathrm{z}$ value) statistics for the equality of group means and medians, respectively. For definitions of the variables see Appendix B. The default probability, which is expressed in basis points (bps) ( 1 basis point $=0.0001)$, is estimated using the model detailed in Appendix A. The sample size varies for different variables because of non-availability of data. Group medians are also reported. **, *, and ${ }^{+}$indicate statistical significance at the $1 \%, 5 \%$, and $10 \%$ level, respectively.

Descriptive statistics for the going private and control samples

\begin{tabular}{|c|c|c|c|c|c|c|}
\hline \multirow{2}{*}{ Variable } & \multicolumn{2}{|c|}{ Going private firm } & \multicolumn{2}{|l|}{ Control firm } & \multirow{2}{*}{$T$} & \multirow{2}{*}{$Z$} \\
\hline & Mean & Median & Mean & Median & & \\
\hline Default prob. (Basis points) & 259.58 & 0.10 & 114.73 & 0.00 & $1.72^{+}$ & $3.98^{* *}$ \\
\hline Distance to default & 4.83 & 4.27 & 6.11 & 5.35 & $-3.69^{* *}$ & $-3.98^{* *}$ \\
\hline Firm size $(£ M)$ & 210.00 & 57.61 & 555.44 & 95.31 & $-3.33^{* *}$ & $-2.98^{* *}$ \\
\hline Operating cash & 0.05 & 0.07 & 0.05 & 0.08 & -0.04 & -1.49 \\
\hline Enterprise value to earnings & 5.35 & 5.25 & 3.18 & 7.41 & 0.89 & $-3.78^{* *}$ \\
\hline Debt to total assets & -0.83 & 0.12 & 0.03 & 0.13 & 0.24 & 0.78 \\
\hline Earnings before interest, etc. & 35.92 & 5.58 & 60.59 & 7.79 & -0.69 & $-1.76^{+}$ \\
\hline Private equity & 6.27 & 8.49 & 12.43 & 13.55 & $-2.83^{* *}$ & $-5.84^{* *}$ \\
\hline Market/ book value of assets & 1.50 & 1.07 & 3.83 & 1.72 & -1.46 & $-5.14^{* *}$ \\
\hline Intangibles & 0.07 & 0.00 & 0.08 & 0 & -0.69 & 1.34 \\
\hline Analysts & 3.56 & 2.00 & 6.92 & 4 & $-5.56^{* *}$ & $-4.01^{* *}$ \\
\hline Analysts above ind. median & 0.45 & 0.00 & 0.6 & 1 & $-3.21^{* *}$ & $-3.17^{* *}$ \\
\hline Board size & 6.60 & 6.00 & 7.24 & 7 & $-3.17^{* *}$ & $-3.10^{* *}$ \\
\hline Non-executives & 0.46 & 0.50 & 0.45 & 0.43 & 0.93 & 1.48 \\
\hline Executive shares & 0.12 & 0.05 & 0.11 & 0.03 & 0.62 & 1.60 \\
\hline Duality & 0.16 & 0.00 & 0.17 & 0 & -0.18 & 0.18 \\
\hline Audit committee & 0.93 & 1.00 & 0.93 & 1 & 0.08 & 0.08 \\
\hline
\end{tabular}




\begin{tabular}{|c|c|c|c|c|c|}
\hline $\begin{array}{l}\text { Default Probability Range (basis } \\
\text { points) }\end{array}$ & $\begin{array}{c}\text { Moody's } \\
\text { Rating }\end{array}$ & Frequency & Percent (\%) & $\begin{array}{l}\text { Cumulative } \\
\text { Frequency }\end{array}$ & $\begin{array}{l}\text { Cumulative } \\
\text { Percent (\%) }\end{array}$ \\
\hline Default Probability $<2$ & Aaa & 124 & 62.31 & 124 & 62.31 \\
\hline $2<$ Default Probability $<=5$ & Aa & 8 & 4.02 & 132 & 66.33 \\
\hline $5<$ Default Probability $<=10$ & A & 9 & 4.52 & 141 & 70.85 \\
\hline $10<$ Default Probability $<=20$ & Baa & 6 & 3.02 & 147 & 73.87 \\
\hline $20<$ Default Probability $<=50$ & $\mathrm{Ba}$ & 6 & 3.02 & 153 & 76.88 \\
\hline $50<$ Default Probability $<=200$ & B & 17 & 8.54 & 170 & 85.43 \\
\hline $200<$ Default Probability $<=400$ & $\mathrm{Caa}$ & 9 & 4.52 & 179 & 89.95 \\
\hline Default Probability $>400$ & $\mathrm{Ca}$ & 20 & 10.05 & 199 & 100.00 \\
\hline
\end{tabular}

Default probability is the default probability before the announcement of the going private deal. The default probability, which is expressed in basis points (bps) ( 1 basis point $=0.0001$ ), is estimated using the model detailed in Appendix A. The default probability ranges correspond to Moody's credit rating categories shown below (See ChanLau, J. A., 2006 for a discussion). However, Moody's KMV model relies on its unique empirical distribution. Since we use normal distribution to arrive at default probability, the segmentation in column 1 of the table is only indicative. Number of firms with Default Probability estimates is 199.

\section{Table 3: Distribution of Default Probability of the P2P sample}


Table 4: Logistic regression model of the going private decision

Dependent variable is coded as 1 for going private firms and 0 for control firms. For variable definitions, see Appendix B. Odds reflect the relative probability of belonging to a category. If $\mathrm{P}$ denotes the probability that an observation belongs to category 1 and (1-P) denotes the probability that it belongs to the second category, Odds ratio $=P /(1-P)$. With odds ratio $>1$, an increase in the value of explanatory variable increases the probability that the sample observation belongs to P2P category. With odds ratio $<1$, an increase in the value of the explanatory variable reduces the probability that the observation belongs to $\mathrm{P} 2 \mathrm{P}$ category. Wald Chi-Square is in parentheses. $* *, *$, and ${ }^{+}{ }^{+}$indicate statistical significance at the $1 \%, 5 \%$, and $10 \%$ level, respectively.

\begin{tabular}{|c|c|c|c|c|}
\hline & & & & \\
\hline Variable & Coefficient & Odds ratio & Coefficient & Odds ratio \\
\hline Intercept & $1.05(2.20)$ & & $1.53(1.36)$ & \\
\hline & $-0.14^{* *}$ & 0.93 & $-0.19^{* *}(14.44)$ & 0.83 \\
\hline Distance to Default & $(14.81)$ & & & \\
\hline Enterprise Value to Earnings & & & $0.00(0.03)$ & 1.00 \\
\hline Debt to total assets & & & $-0.93^{*}(3.69)$ & 0.40 \\
\hline Earnings before interest, etc. & & & $0.00(0.43)$ & 1.00 \\
\hline Market to book value of assets & & & $-0.02(1.18)$ & 0.98 \\
\hline Operating cash flow & & & $1.46(2.11)$ & 4.31 \\
\hline Intangibles & & & $0.59(0.41)$ & 1.81 \\
\hline Analysts & & & $-0.09^{* *}(12.37)$ & 0.91 \\
\hline Board size & & & $-0.08(1.21)$ & 0.93 \\
\hline Non-executives & & & $0.02^{*}(3.69)$ & 1.02 \\
\hline Executive shares & & & $0.04^{+}(3.33)$ & 1.05 \\
\hline Executive shares squared & & & $-0.001^{+}(3.57)$ & 1.00 \\
\hline Duality & & & $-0.36(0.81)$ & 0.70 \\
\hline Audit committee & & & $-0.50(0.72)$ & 0.60 \\
\hline Year Dummy & yes & & Yes & \\
\hline Number of observations & 368 & & 320 & \\
\hline Max-rescaled R-Square & 0.06 & & 0.25 & \\
\hline Wald Chi-Square & $14.81^{\mathrm{c}}$ & & $46.67^{* *}$ & \\
\hline
\end{tabular}


Table 5 Exit mode of the going private firms-Descriptive statistics

The sample comprises of 246 UK going private deals from 1997 to 2005 . Within the sample, the exit mode data is available for 217 P2P deals. Further, default probability data are available for 182 targets. In Panel A, for the firms that are still held by a private equity fund, i.e. Exit is designated as "None", holding period is defined as the period till the end of December 2005. Exit modes are discussed in Section 4.5 of the text. Distance to default and default probability are defined in Appendix B.

Panel A: Holding period (months) classified by exit mode

\begin{tabular}{lrrrrrr}
\hline Exit Mode & Sample size & Mean & Median & Max & Min & Std \\
\hline Receivership & 10 & 41 & 44 & 63 & 6 & 18 \\
Initial public offering & 11 & 42 & 30 & 84 & 20 & 23 \\
Trade Sale & 21 & 45 & 42 & 89 & 7 & 24 \\
Secondary buyout & 23 & 46 & 41 & 97 & 16 & 24 \\
None & 152 & 50 & 52 & 102 & 0 & 26 \\
\hline
\end{tabular}

Panel B: Default probability in basis points and distance to default classified by exit mode

\begin{tabular}{lrrr}
\hline Exit Mode & Sample size & $\begin{array}{r}\text { Mean Default Probability } \\
\text { (Median) }\end{array}$ & $\begin{array}{r}\text { Mean Distance to Default } \\
\text { (Median) }\end{array}$ \\
\hline Receivership & 9 & $376.00(72.71)$ & $2.76(2.44)$ \\
Initial public offering & 9 & $51.23(7.36)$ & $4.02(3.18)$ \\
Trade Sale & 21 & $73.54(0.00)$ & $4.90(4.97)$ \\
Secondary buyout & 21 & $200.89(0.00)$ & $5.39(4.92)$ \\
None & 122 & $168.10(0.11)$ & $5.13(4.24)$ \\
\hline
\end{tabular}

Panel C Default probability in basis points and distance to default of receivership exit targets

\begin{tabular}{|c|c|c|c|c|c|c|}
\hline Obs & Company name & P2P Date & $\begin{array}{l}\text { Distance- } \\
\text { to-default }\end{array}$ & $\begin{array}{r}\text { Default } \\
\text { Probability }\end{array}$ & $\begin{array}{r}\text { Deal } \\
\text { Value } \\
(£ M)\end{array}$ & $\begin{array}{r}\text { Holding period } \\
\text { in months }\end{array}$ \\
\hline$\overline{1}$ & UK Safety PLC & 20-Mar-98 & 1.79 & 365.82 & 1.01 & 64 \\
\hline 2 & Bucknall Group PLC & 28-Aug-98 & 3.21 & 6.61 & 14.8 & 54 \\
\hline 3 & UPF Group PLC & 4-Sep-98 & 4.48 & 0.04 & 42.8 & 39 \\
\hline 4 & Crest Packaging PLC & 2-Dec-98 & 2.07 & 190.29 & 16.4 & 53 \\
\hline 5 & Greycoat & 21-May-99 & 4.08 & 0.22 & 282.5 & 61 \\
\hline 6 & Lambert Fenchurch & 22-Nov-99 & 1.18 & 1181.98 & 130.94 & 49 \\
\hline 7 & Finelist/Europe Auto Distn & 14-Feb-00 & 2.44 & 72.71 & 159.2 & 8 \\
\hline 8 & QS Group plc/Hamsard & 26-Sep-02 & 4.57 & 0.02 & 15.8 & 41 \\
\hline 9 & Chesterton International & 17-Apr-03 & 1.01 & 1566.32 & 10.2 & 23 \\
\hline
\end{tabular}


Table 6 Exit mode of targets with high default probability ( $>400$ basis points) 
Table 7 Exit mode of the going private firms-Logistic regression

The dependent variable is 1 if exit mode is receivership and 0 for all other outcomes. For variable definitions see Appendix B. If P denotes the probability that an observation belongs to category 1 and (1-P) denotes the probability that it belongs to the second category, Odds ratio $=P /(1-P)$. With odds ratio $>1$, an increase in the value of explanatory variable increases the probability that the sample observation belongs to P2P category. With odds ratio $<1$, an increase in the value of the explanatory variable reduces the probability that the observation belongs to $\mathrm{P} 2 \mathrm{P}$ category. Wald Chi-Square is in parentheses. ${ }^{\mathrm{a}, \mathrm{b}}$ and ${ }^{\mathrm{c}}$ indicate statistical significance at the $1 \%, 5 \%$, and $10 \%$ level, respectively

\begin{tabular}{|c|c|c|c|c|}
\hline \multirow{2}{*}{ Variable } & \multicolumn{2}{|c|}{ Model 1} & \multicolumn{2}{|c|}{ Model 2} \\
\hline & Coefficient & Odds ratio & Coefficient & Odds ratio \\
\hline Intercept & $-1.59(6.94)$ & & $2.08(0.38)$ & \\
\hline Distance to default & $-0.37^{b}(4.81)$ & 0.69 & $-0.96^{\mathrm{b}}(6.11)$ & 0.38 \\
\hline $\begin{array}{l}\text { Enterprise value to } \\
\text { earnings before interest, } \\
\text { tax, depreciation and } \\
\text { amortization }\end{array}$ & & & $0.00(0.11)$ & 1.00 \\
\hline $\begin{array}{l}\text { Debt to total assets } \\
\text { earnings before interest, } \\
\text { tax, depreciation and } \\
\text { amortization to interest } \\
\text { costs }\end{array}$ & & & $\begin{array}{r}2.46(0.88) \\
0.01^{\mathrm{b}}(4.77)\end{array}$ & $\begin{array}{r}11.75 \\
1.01\end{array}$ \\
\hline Market to book value & & & $0.06(0.86)$ & 1.06 \\
\hline Operating cash flow & & & $9.98(1.65)$ & $>999.999$ \\
\hline Intangibles & & & $-3.66(0.26)$ & 0.03 \\
\hline $\begin{array}{l}\text { Analysts above } \\
\text { industry median }\end{array}$ & & & $0.10(0.01)$ & 1.10 \\
\hline Board size & & & $0.29(1.14)$ & 1.34 \\
\hline Non-executives & & & $-0.09^{\mathrm{b}}(4.45)$ & 0.91 \\
\hline Executive shares & & & $-0.11(1.65)$ & 0.90 \\
\hline $\begin{array}{l}\text { Executive } \quad \text { shares } \\
\text { squared }\end{array}$ & & & $0.00(1.91)$ & 1.00 \\
\hline Duality & & & $1.80(2.09)$ & 6.04 \\
\hline Management buyout & & & $-2.96^{\mathrm{b}}(5.47)$ & 0.05 \\
\hline Year Dummy & & & Yes & \\
\hline Observations & 182 & & 181 & \\
\hline $\begin{array}{ll}\text { Max-rescaled } & \text { R- } \\
\text { Squared } & \\
\text { Wald Chi-Square } & \end{array}$ & $\begin{array}{r}0.1 \\
4.81^{\mathrm{b}}\end{array}$ & & $\begin{array}{r}0.46 \\
13.85\end{array}$ & \\
\hline
\end{tabular}


${ }^{1}$ Rigorous statistical models to predict financial distress or bankruptcy have a long history going back to at least 1968 when Altman reported his discriminant model (see Wilson et al (2009) for references to some of these models). These models are generally based on financial statement numbers. The option pricing approach used in our study is of recent vintage and relies on market based valuation and volatility measures and therefore allows us to use data more proximate to the P2P transaction. They also reflect the market view of bankruptcy risk. This approach is used extensively to estimate default probabilities and price corporate debt and calculate the debt premium on bonds. One shortcoming of the DD measure is that it cannot capture individual institutions' risks well over short time horizons because asset prices are not allowed to be discontinuous and the level of liabilities is assumed constant (Chan-Lau and Gravelle, 2005). As regards the assumption of continuous asset price changes in our analysis using the Merton [1974] model, we assume that asset value follows a geometric Brownian motion process. It is also possible to assume the underlying asset value follows a Levy process. Previous studies including Lipton [2002], Cariboni and Schoutens [2007], and Madan and Schoutens [2008] examine a Levy process that incorporates jumps in the dynamics of the asset value and their implications on firm default probability as well as credit spread. The Levy-based model normally studies the path dependency of firm value evolution and is solved numerically. In this study, we opt for the Merton [1974] model for the sake of computational simplicity and we leave the Levy process extension for future study. We calculate the distance to default at company level, i.e, thus avoiding the potential problem of misleading estimates of systemic risk if we were to aggregate DD at the sector level (Chan-Lau and Gravelle, 2005). Sectoral or fund level analyses based on DD that aggregate individual firms' balance sheets and equity market values into one fictitious "megafirm" may produce average default risks that are not representative of systemic default risk in the system.

${ }^{2}$ In practice, MTBV is often used by analysts as a measure of valuation and therefore as a proxy for over- or under-valuation. We also report tests based on the price-earnings ratio as an alternative to MTBV. 